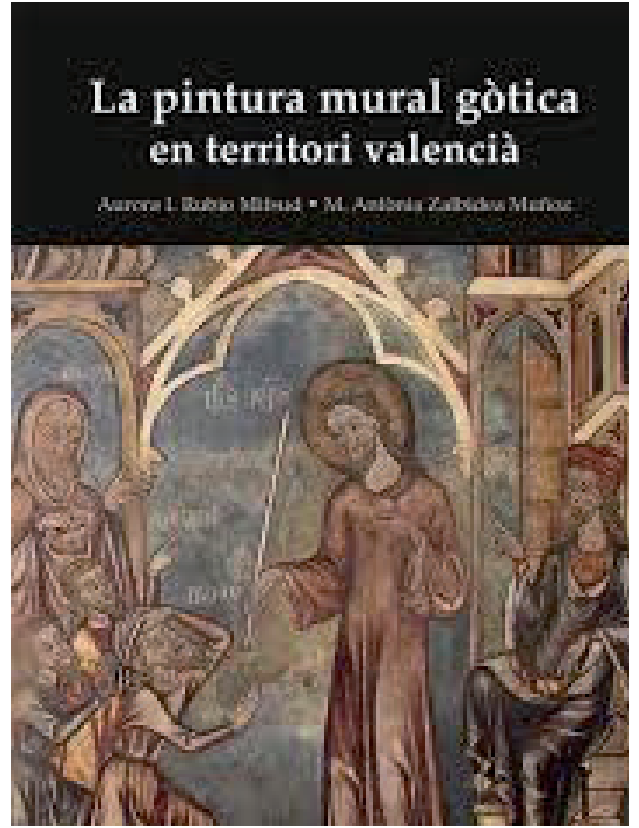

\section{La pintura Mural Gótica en territori valencià}

\author{
Rubio Misfud Aurora; Zalbidea Muñoz, M. Antonia
}

Editor: Onada Edicions, 2019.

ISBN: 978-84-16505-76-0

Dimensiones: $215 \times 305 \mathrm{~mm}$

Páginas: 144 p. (a color)

Idioma: catalán
El arte medieval es probablemente uno de los capítulos más interesantes de la historia cultural de nuestro territorio, aunque, paradójicamente, el reducido volumen de obras y la escasez documental, hagan de él, todavía, un asunto sobre el que queda abundante espacio de trabajo y de reflexión. Una de las evidencias artísticas más desconocidas y raras en el ámbito artístico de la Corona de Aragón es, precisamente, su pintura mural gótica, mucho menos estudiada y sistematizada que las manifestaciones plásticas románicas que ornaron los muros de no pocas iglesias del norte de Cataluña y Aragón. En cambio, Valencia, no gozó probablemente de pinturas murales de tradición cristiana hasta al menos la segunda mitad del siglo XIII, momento en el que, ya consumada la Conquista, se fueron definiendo los límites del Reino. De hecho, dentro del territorio peninsular de la Corona de Aragón, Valencia desempeñó un rol decisivo en términos artísticos: se erigió como un crisol en el que se fundieron los diversos lenguajes plásticos del gótico, entre los siglos XIII y XV, hecho que acabaría por forjar una escuela deudora de las aportaciones francas, itálicas $y$, posteriormente, flamencas, asumidas desde la práctica de la tradición pictórica local. Aun con ello, la pintura mural gótica valenciana ha sido siempre un epígrafe desatendido; obviado por la escasez de ejemplos, por la mala conservación de estos y por la circunstancia de estar ligada a los avatares de los propios edificios, de los que intrínsecamente depende. Queda relegada, en fin, a un irrelevante segundo plano, quizás a la sombra de las florecientes manifestaciones pictóricas muebles que, en cambio, en el ámbito de la pintura, abanderaron la colorista eclosión del gótico valenciano.

La ausencia de estudios al respecto de la pintura mural gótica en el antiguo reino de Valencia resultaba, hasta ahora, cuanto menos llamativa, especialmente si se compara con las profusas investigaciones que en materia de retablística han venido desarrollándose desde inicios del siglo XX. Probablemente, haya sido esa carencia la que haya empujado a las Dras. Rubio y Zalbidea, especialistas en conservación de pintura mural, a encargarse del estudio de tal ámbito. Bajo el título La pintura mural gòtica en territori valencià, las autoras proponen un viaje de exploración de diversas manifestaciones murales entre los siglos XIII y XIV, como no se había hecho aún hasta el presente.

A través de sus páginas se nos ofrece una metódica inmersión en un fenómeno pictórico que debió de ser mucho más usual de lo que a priori pueda considerarse: huelga decir que muchas de las pinturas se fueron perdiendo con el paso de los años; se destruyeron por razones de remodelación, adaptación o demolición de los edificios; o, incluso, como se plantea en el último epígrafe, simplemente subyacen bajo capas de cal, aguardando todavía a ser descubiertas. En cualquier caso, son las evidencias visibles las que acaparan el protagonismo de este estudio. El criterio es sistemático, ajeno a cuestiones de calidad o relevancia: cualquier resto de pintura mural gótica, por trivial, escaso, o irrelevante que pudiera parecer, encuentra atención en las páginas de este libro.

Cabe decir, en primer lugar, que se trata de un planteamiento metodológico tan completo como complejo, pues el enfoque bascula entre los tradicionales estudios formales de la Historia del Arte y una nueva 'metaformalidad' (asumida desde la óptica del conservadorrestaurador), que incurre en la observación técnica y procedimental de las pinturas. Las autoras parten de la revisión de las fuentes documentales, referencias histórico- 
artísticas, documentación dispersa (oral y escrita) e informes de conservación-restauración, y prosiguen con una exhaustiva campaña de cartografía y documentación gráfica. Todo ello les permite enfrentarse metódicamente a un análisis formal, fundamentado en la comparación entre los más de 70 conjuntos murales que configuran el corpus inventariado de restos de este periodo en territorio valenciano. Como resultado ponen de manifiesto aspectos histórico-artísticos, estilísticos, e iconográficos que habían pasado desapercibidos. Llegan a documentar, por ejemplo, el reciclaje de motivos, o el empleo de patrones idénticos en la gestación compositiva, evidenciando profusas relaciones entre algunos de los conjuntos.

Muy interesante resulta la contribución de los resultados arrojados por el empleo de análisis fisico-químicos, que permiten un acercamiento cualitativo y empírico a la observación directa de las obras. Se trata este de un aspecto para nada baladí: la investigación rebasa los límites de la metodología histórico-artística y va creciendo y vertebrándose con aportaciones sobre la técnica pictórica, sus materiales o el estado de conservación. Esto fomenta una lectura material, a todas luces necesaria: abordar el examen de las pinturas desde las propias limitaciones del procedimiento de ejecución y de los materiales integrantes. Ello supone aventurar un estatus diferente para estas; imaginar otra apariencia formal, alejada de su aspecto actual, incluyendo una lectura atenta a las metodologías de intervención sobre el patrimonio. El estudio evidencia, por ejemplo, que muchas de las actuaciones en materia de conservación-restauración ejecutadas sobre las pinturas del gótico valenciano, se realizaron con criterios muy dispares.

El libro se estructura en dos grandes bloques. Uno inicial se dedica al contexto histórico-artístico del arte gótico en territorio valenciano, a los materiales y técnicas de la pintura mural gótica y a un sucinto estudio de inventario y catalogación de ejemplares. La segunda parte se centra en la pintura figurativa, abordando todos los ejemplos conservados, desde la antedicha óptica. Podría decirse que constituye un afortunado intento de sistematización y ordenación del desconocido corpus de la pintura gótica mural; una suerte de catálogo que, recorre vertebralmente el territorio del antiguo Reino de Valencia, elencando cada conjunto mural. El estudio comprende pinturas en Morella, Ademús, LLiria, Xàtiva, Gandia, Ontinyent y València, entre otras poblaciones. Se incluyen cerca de doscientas imágenes en color: fotografías de detalle, macrofotografías y microfotografías superficiales, con las que el lector experimenta una inmersión en conjuntos murales que, en muchas ocasiones resultan de difícil acceso.

Se trata, en resumen, de una publicación caracterizada por un planteamiento enriquecedor, que en lo sucesivo, debería considerarse como punto de partida para ulteriores investigaciones: un ejemplo de transversalidad a caballo entre una mirada descriptiva, narrativa y formal, y otra analítica, técnica, material y procedimental. Las autoras son conscientes de que se ocupan de un tema 'abierto', pues en el futuro es muy posible que nuevos hallazgos permitan ir engrosando el corpus de pinturas murales del gótico en Valencia. En cualquier caso, supone una aportación fundamental para la puesta en valor de un patrimonio realmente relevante, aunque, paradójicamente, ignoto.

Miquel Àngel Herrero-Cortell Universidad Politécnica de Valencia

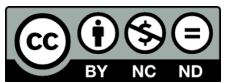

https://doi.org/10.37558/gec.v18i1.804 